\title{
PERBANDINGAN LAJU SEDIMENTASI DAN KARAKTERISTIK SEDIMEN DI MUARA SOCAH BANGKALAN DAN PORONG SIDOARJO
}

Comparison Rate of Sedimentation and Sediment Characteristics in Estuary Socah Bangkalan and Porong Sidoarjo

\author{
Rista Rosyadewi ${ }^{1}$ dan Zainul Hidayah ${ }^{2 *}$
}

${ }^{1}$ Mahasiswa program Studi IImu Kelautan, Universitas Trunojoyo Madura

${ }^{2}$ Dosen Program Studi IImu Kelautan, Universitas Trunojoyo Madura

*Corresponding author email: zain.hidayah99@gmail.com

Submitted: 27 February 2020 / Revised: 27 February 2020 / Accepted: 27 February 2020

http://doi.org/10.21107/juvenil.v111.6832

\begin{abstract}
Sedimentation is the precipitation event or a buildup of rock material transported by water or wind power somewhere (Hambali 2016). Sediment is a splinter of rock that have varying sizes and shapes are formed from chemical and physical processes in these rocks. Sedimentation rate is the amount of sediment mass which is taken through a unit area in each unit time. The purpose of this study was to determine the comparative value of sedimentation rate and the characteristics of the sediment in the estuary Socah Bangkalan and Porong Sidoarjo. This study was conducted during one month starting on 21 November to 22 December 2018 the two stations (Socah and Porong estuary). The tools used in the field sampling was Sediment Trap for a large measure sedimentation, while to analyze the characteristics of the sediment using a wet analysis or pipetting. Sedimentation rate value comparison test using statistical test of Independent Sample T-Test. Research results obtained value Socah sedimentation in the estuary for 15 days for $1,02 \mathrm{~m}^{3}$ /day and in Porong estuary of 1,98 $\mathrm{m}^{3} /$ day. Sediment type that prevailed in those two locations manifold to Silt (mud). The results of the sedimentation rate at both locations have significantly different values (significant) statistically with test results showing the Sig. (2-tailed) of 0,000 where the value $\leq 0,05$.
\end{abstract}

Keywords : Sedimentation, Sedimentation Rate, Sediment Characteristics, Estuary Socah Bangkalan and Porong Sidoarjo

\section{ABSTRAK}

Sedimentasi merupakan peristiwa pengendapan atau penumpukan material batuan yang terangkut oleh tenaga air maupun angin di suatu tempat (Hambali 2016). Sedimen merupakan pecahan batuan yang memiliki ukuran dan bentuk yang bervariasi yang terbentuk dari proses fisika dan kimia pada batuan tersebut. Laju sedimentasi adalah banyaknya massa sedimen yang terangkat melalui satu satuan luas dalam setiap satuan waktu. Tujuan penelitian ini adalah untuk mengetahui perbandingan nilai laju sedimentasi dan karakteristik sedimen di muara Socah Bangkalan dan Porong Sidoarjo. Penelitian ini dilakukan selama 1 bulan mulai tanggal 21 November - 22 Desember 2018 di dua stasiun (muara Socah dan Porong). Alat yang digunakan dalam pengambilan sampel lapang adalah Sedimen Trap untuk mengukur besar pengendapan sedimen, sedangkan untuk menganalisis karakteristik sedimen dengan menggunakan analisa basah atau pemipetan. Uji perbandingan nilai laju sedimentasi menggunakan Uji statistik Independent Sampel T-Test. Hasil penelitian yang didapat yaitu nilai laju sedimentasi di muara Socah selama 15 hari sebesar 1,02 $\mathrm{m}^{3} /$ hari dan di muara Porong sebesar 1,98 $\mathrm{m}^{3} /$ hari. Jenis sedimen yang mendominasi pada ke dua lokasi tersebut berjenis Silt (lumpur). Hasil laju sedimentasi pada kedua lokasi mempunyai nilai yang berbeda nyata (signifikan) secara statistik dengan hasil uji menunjukkan nilai Sig. (2-tailed) sebesar 0,000 dimana nilai tersebut $\leq 0,05$.

Kata Kunci : Sedimentasi, Laju Sedimentasi, Karakteristik Sedimen, Muara Socah Bangkalan dan Porong Sidoarjo

\section{PENDAHULUAN}

Daerah muara sungai merupakan daerah yang memiliki produktifitas yang tinggi. Hal tersebut dikarenakan pada daerah muara mengalami penambahan bahan - bahan organik maupun anorganik yang berasal dari daratan yang mengalir melalui aliran sungai dan perairan di 
sekitarnya yang terjadi secara terus menerus. Bertemunya atau bercampurnya air tawar dari sungai dan air asin dari laut di daerah muara sungai menyebabkan terjadinya perubahan kondisi fisik oseanografi di daerah tersebut. Selain itu, aktifitas transportasi yang padat serta pemanfaatan wilayah secara itensif sebagai kawasan pemukiman, pusat pemeritahan, pertambakan dan industri, memberikan tekanan yang besar dan mempengaruhi keberlangsungan sumberdaya perairan. Sehingga, dapat mengakibatkan timbulnya permasalahan, seperti perubahan garis pantai dan pendangkalan akibat sedimentasi. Proses tersebut yang terjadi secara terus menerus tanpa adanya penanganan dapat menghambat aliran air dan menaikkan muka air laut (Putra et al., 2016).

Bahan - bahan organik yang terbawa oleh aliran air salah satunya adalah material sedimen. Material sedimen tersebut akan terbawa sampai di daerah muara sungai dan akan mengendap pada daerah tersebut. Material sedimen merupakan pecahan batuan, atau mineral organik yang diangkut dari berbagai sumber dan diendapkan pada suatu tempat (Triatmojo, 1999). Laju sedimentasi atau kecepatan laju endapan sedimen dipengaruhi oleh ukuran partikel sedimen dan dipengaruhi oleh debit yang melewati penampang pada daerah tersebut. Dimana debit aliran adalah fungsi dari kedalaman aliran (d), lebar sungai (b) dan kemiringan energi (So) (Hambali, 2016). Pengukuran laju sedimentasi dapat mengguanakan alat sediment trap untuk mengukur jumlah atau volume sedimen terakumulasi. Menurut Rifardi, (2012) alat ini biasanya diletakkan pada kedalaman sesuai dengan yang dinginkan. Akumulasi sedimen digunakan untuk menjelaskan jumlah (volume dan berat) sedimen yang mengendap persatuan luas area per waktu (Rifardi, 2008).

Pengendapan material sedimen pada daerah muara sungai terjadi karena tenaga pengangkut sedimen sudah tidak sanggup untuk membawanya. Kecepatan arus akan cenderung melemah ketika mencapai daerah muara sungai, sehingga sedimen yang terangkut akan mengendap pada daerah tersebut atau di sekitar muara. Peristiwa pengendapan atau penumpukan sedimen di perairan disebut sedimentasi. Sedimentasi yang terjadi pada daerah muara dapat menyebabkan berkurangnya kecepatan aliran sungai yang melintas dan mengakibatkan banjir di sekitar muara. Proses pasang surut air laut serta perbedaan densitas air laut dan sungai dapat menyebabkan terjadinya pendangkalan pada muara sungai.

Muara Socah terletak di Kabupaten Bangkalan, yang merupakan daerah ujung barat dari Pulau Madura dan bagian dari Selat Madura. Muara ini memiliki peranan penting sebagai jalur transportasi umum yang menghubungkan beberapa daerah bila ditinjau dari aktifitas ekonomi. Selain itu, terdapat beberapa industri pabrik di kawasan pesisir perairan tersebut. Adapun Muara Porong terletak di Kabupaten Sidoarjo, menjadi tempat bertemunya air dari Sungai Porong dengan perairan Selat Madura. Muara Porong memiliki karakteristik perairan yang sangat dinamis. Terdapat beberapa sungai yang mengalirkan air dan beberapa material organik maupun anorganik menuju daerah muara Porong salah satunya sungai Brantas dan sungai Porong. Kedua sungai tersebut memiliki peranan penting pada terjadinya proses sedimentasi pada daerah muara Porong. Sungai Brantas memberikan suplai material sedimen cukup besar pada muara Porong.

Kondisi dan dinamika Muara Socah dan Porong yang dimungkinkan mendapat pengaruh dari faktor fisika, biologi, dan kimia lautan dan daratan mendorong peneliti untuk melakukan penelitian terhadap perbedaan laju sedimentasi dan karakteristik dari sedimen diharapkan mampu mengetahui berapa besar (volume) pengendapan pada kedua lokasi tersebut, karena terjadinya pendangkalan pada daerah muara dapat mengkibatkan penurunan kecepatan aliran sungai dan terjadinya banjir di muara tersebut. Dengan demikian hasil penelitian ini diharapkan mampu dijadikan salah satu alternatif untuk mengetahui volume pengendapan atau laju sedimentasi setiap harinya pada muara Socah dan Porong.

\section{Waktu dan Tempat}

\section{MATERI DAN METODE}

Penelitian laju sedimentasi dilakukan dengan pangambilan sampel di lapang berupa sedimen dan analisa di laboratorium. Pengambilan sampel dilaksanakan pada tanggal 21 November - 22 Desember 2018 di muara Socah Bangkalan yang terletak di desa Keramat Socah Bangkalan dan Muara Porong Sidoarjo. 

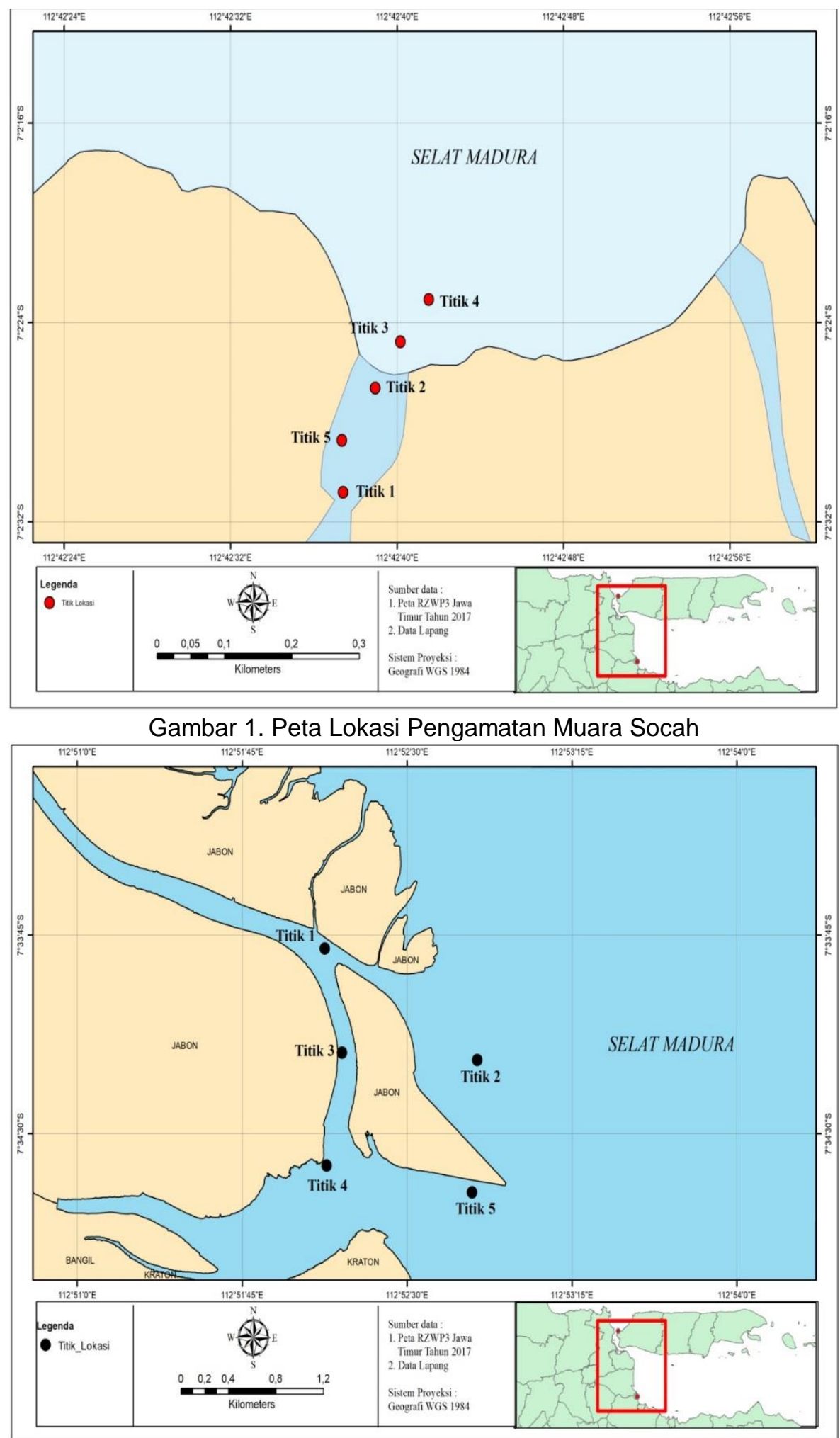

\section{Prosedur Penelitian}

\section{Pengambilan Sampel Sedimen}

Pengambilan sampel sedimen menggunakan alat yaitu Sediment Trap. Pemasangan alat sedimen trap ini dilakukan pada saat kondisi perairan surut tetapi dengan syarat alat Sediment Trap tetap terendam dengan air. Alat ini digunakan untuk menangkap sedimen melayang yang terbawa oleh arus dan gelombang dan aliran sungai menuju daerah muara. Alat ini memiliki volume tabung yang berfungsi untuk mengetahui berat atau volume akumulasi sedimen yang masuk pada periode waktu tertentu yang nantinya akan digunakan dalam perhitungan laju sedimentasi 
Metode Analisa Sampel Sedimen

Analisa sampel yang dilakukan adalah melihat dan memegang sedimen untuk mengetahui tekstur dari sedimen. Kemudian analisa selanjutnya adalah analisa ukuran butir untuk mengetahui jenis butir sedimen. Analisa ukuran butir sedimen dilakukan analisis pemipetan dengan metode Buchanan (1984) dalam Pradipta et al., (2013). Sampel sedimen yang menggumpal akan dianalisa menggunakan analisa basah atau pemipetan. Selain itu menghitung dari berat sampel untuk perhitungan kecepatan laju sedimentasi dengan cara mengoven dan menimbang sampel dengan neraca analitik dan melakukan perhitungan.

\section{Perhitungan Laju Sedimentasi}

Menurut Srijati, (2017) pengukuran laju sedimentasi dapat dihitung menggunakan rumus:

$$
\begin{aligned}
& \text { Laju sedimentasi }=\mathrm{A}-\mathrm{B} / \text { Luas/minggu } \\
& \text { (gram/luas paralon/minggu) } \\
& =\left(10000 / \pi \cdot r^{2}\right) \cdot(A-B)\left(\text { gram } / \mathrm{m}^{2} / \text { hari }\right) \\
& =\left(10 / \pi \cdot r^{2}\right) \cdot(A-B)\left(\mathrm{kg} / \mathrm{m}^{2} / \text { hari }\right) \\
& =\left(10 / \pi \cdot r^{2}\right) \cdot(A-B) / 0,75\left(\mathrm{~m}^{3} / \text { hari }\right)
\end{aligned}
$$

Keterangan :

$A=$ berat kertas + sampel sedimen (gram)

$\mathrm{B}=$ berat kertas (gram)

$\pi=3,14$

$r=$ jari-jari lingkaran Sedimen trap

Nilai laju sedimentasi dikonversi menjadi satuan m3/hari dengan cara membagi dengan massa jenis sedimen yaitu 0,75 (Fajarin et al., 2014)

\section{Analisa Parameter Hidrooseanografi}

Parameter hidrooseanografi berupa data arus laut dan pasang surut dalam penelitian ini tidak dilakukan pengukuran langsung di lapang. Data pasang surut diperoleh dari web BIG TIDE dan data arus berasal dari Peta RZWP3K Jawa Timur Tahun 2017 yang digunakan sebagai data penunjang hasil penelitian dimana telah disesuaikan dengan titik lokasi pengambilan sampel sedimen. Data arus laut yang didapat dikoreksi dengan menggunakan Microsoft Excel untuk memperoleh nilai arah dan kecepatan arus laut. Data arus dipisahkan berdasarkan kondisi pasang dan kondisi surut yang biasa terjadi di Indonesia. Data tersebut kemudian diolah menggunakan Software Arcgcis 10.2 dengan Metode IDW, sehingga terbentuk pola arus laut.

\section{HASIL DAN PEMBAHASAN Laju Sedimentasi}

Laju sedimentasi merupakan banyaknya (volume) sedimen yang terangkat per satuan luas per satuan waktu. Kecepatan sedimen untuk mengendap dipengaruhi oleh beberapa faktor diantaranya kecepatan arus, debit sungai, pasang surut maupun faktor hidrooseanografi yang lain. Pengukuran laju sedimentasi dilakukan dengan menggunakan Sedimen Trap yang dipasangkan di 2 stasiun dengan 5 titik lokasi. Adapun hasil pengolahan

\begin{tabular}{|c|c|c|c|c|c|}
\hline \multirow{2}{*}{ Pengambilan } & \multirow{2}{*}{$\begin{array}{l}\text { Tanggal } \\
\text { Pengambilan }\end{array}$} & \multirow{2}{*}{$\begin{array}{l}\text { Debit Sungai } \\
\left(\mathrm{m}^{3} / \text { detik) }\right.\end{array}$} & \multicolumn{3}{|c|}{ Laju sedimentasi } \\
\hline & & & $\mathrm{gr} / \mathrm{m}^{2} / \mathrm{hari}$ & $\mathrm{kg} / \mathrm{m}^{2} / \mathrm{hari}$ & $\mathrm{m}^{3} /$ hari \\
\hline 1 & $24 / 11 / 2018$ & 81,01 & 1898,42 & 1,9 & 1,08 \\
\hline 2 & $27 / 11 / 2018$ & 50,04 & 1743,34 & 1,74 & 1,00 \\
\hline 3 & $30 / 11 / 2018$ & 44,77 & 1243,68 & 1,24 & 0,71 \\
\hline 4 & 03/12/2018 & 82,33 & 2177,91 & 2,18 & 1,24 \\
\hline 5 & 06/12/2019 & 74,53 & 1873,17 & 1,87 & 1,07 \\
\hline Rata - rata 15 hari & & & 1787,3 & 1,79 & 1,02 \\
\hline
\end{tabular}
data lapang laju sedimentasi selama 15 hari pada stasiun 1 (Muara Socah) dapat dilihat pada Tabel 1.

Tabel 1. Laju Sedimentasi Muara Socah ( $\mathrm{m}^{3} /$ hari)

Pada stasiun 1 (Socah) hasil perhitungan rata -- rata pada setiap pengambilan laju sedimentasi berkisar antara 1,24 kg/m²/hari $2,18 \mathrm{~kg} / \mathrm{m}^{2} /$ hari, sedangkan volume laju sedimentasi rata - rata disetiap pengambilan berkisar antara $0,71 \mathrm{~m}^{3} /$ hari - 1,24 $\mathrm{m}^{3} /$ hari. Hasil laju sedimentasi terbesar berada pada pengambilan ke 4 dengan nilai sebesar 2,18 $\mathrm{kg} / \mathrm{m}^{2} /$ hari atau $1,24 \mathrm{~m}^{3} /$ hari dengan debit rata
- rata $82,33 \mathrm{~m}^{3} /$ detik. Sedangkan nilai terkecil dari laju sedimentasi adalah pada pengambilan ke 3 dengan nilai $1,24 \mathrm{~kg} / \mathrm{m}^{2} /$ hari atau 0,71 $\mathrm{m}^{3} /$ hari dengan debit rata - rata $44,77 \mathrm{~m}^{3} /$ detik. Nilai rata - rata laju sedimentasi dalam 15 hari pada stasiun 1 (Socah) mempunyai nilai 1,02 $\mathrm{m}^{3} /$ hari. Adapun hasil pengolahan data lapang laju sedimentasi selama 15 hari pada stasiun 2 (Muara Porong) dapat dilihat pada Tabel 2. 
Tabel 2. Laju Sedimentasi Muara Porong ( $\mathrm{m}^{3} /$ hari)

\begin{tabular}{|c|c|c|c|c|c|}
\hline \multirow{2}{*}{ Pengambilan } & \multirow{2}{*}{$\begin{array}{l}\text { Tanggal } \\
\text { Pengambilan }\end{array}$} & \multirow{2}{*}{$\begin{array}{l}\text { Debit sungai } \\
\left(\mathrm{m}^{3} / \text { detik) }\right.\end{array}$} & \multicolumn{3}{|c|}{ Laju sedimentasi } \\
\hline & & & gr $/ \mathrm{m}^{2} /$ hari & $\mathrm{kg} / \mathrm{m}^{2} / \mathrm{hari}$ & $\mathrm{m}^{3} /$ hari \\
\hline 1 & $10 / 12 / 2018$ & 114,58 & 2468,70 & 2,47 & 1,41 \\
\hline 2 & $13 / 12 / 2018$ & 144,32 & 3907,17 & 3,91 & 2,23 \\
\hline 3 & $16 / 12 / 2018$ & 128,88 & 3631,81 & 3,63 & 2,08 \\
\hline 4 & $19 / 12 / 2018$ & 138,25 & 3636,32 & 3,64 & 2,08 \\
\hline 5 & $22 / 12 / 2018$ & 143,31 & 3681,37 & 3,68 & 2,10 \\
\hline Rata - rata 15 hari & & & 3465,07 & 3,47 & 1,98 \\
\hline
\end{tabular}

Pada stasiun 2 (Porong) hasil perhitungan rata - rata pada setiap pengambilan laju sedimentasi berkisar antara $2,47 \mathrm{~kg} / \mathrm{m}^{2} /$ hari $3,91 \mathrm{~kg} / \mathrm{m}^{2} /$ hari, sedangkan volume laju sedimentasi rata - rata disetiap pengambilan berkisar antara $1,41 \mathrm{~m}^{3} /$ hari - 2,23 $\mathrm{m}^{3} /$ hari. Hasil laju sedimentasi terbesar berada pada pengambilan ke 2 dengan nilai sebesar 3,91 $\mathrm{kg} / \mathrm{m}^{2} /$ hari atau $2,23 \mathrm{~m}^{3} /$ hari dengan debit rata - rata 144,32 $\mathrm{m}^{3} /$ detik. Sedangkan nilai terkecil dari laju sedimentasi adalah pada pengambilan ke 1 dengan nilai $2,47 \mathrm{~kg} / \mathrm{m}^{2} /$ hari atau 1,41 $\mathrm{m}^{3} /$ hari dengan debit rata -- rata 114,58 $\mathrm{m}^{3} /$ detik. Nilai rata - rata laju sedimentasi dalam 15 hari pada stasiun 2 (Porong) mempunyai nilai $1,98 \mathrm{~m}^{3} /$ hari.

Rata - rata nilai laju sedimentasi di muara Socah antara $0,7107 \mathrm{~m}^{3} /$ hari $-1,2445 \mathrm{~m}^{3} /$ hari dan muara Porong antara $1,41069 \mathrm{~m}^{3} /$ hari $2,23269 \mathrm{~m}^{3} /$ hari. Hal ini bisa disebabkan oleh beberapa faktor diantaranya adalah luasan wilayah muara, debit aliran sungai, arus serta pasang surut pada daerah tersebut. Srijati et al., (2017), debit suspensi akan mempengaruhi besar kecilnya nilai laju sedimentasi yang terdapat di muara sungai karena debit tersebut membawa sedimen tersuspensi yang akan terendapkan di dasar perairan saat kecepatan aliran sungai menuju laut tidak mampu lagi membawa material sedimen sehingga akan menyebabkan pendangkalan pada daerah muara.

\section{Peta Laju Sedimentasi Muara Socah}

Berdasarkan hasil laju sedimentasi yang didapat akan dilakukan pengklasifikasian tingkat nilai laju sedimentasi dalam bentuk peta. Nilai yang diplotkan pada peta laju sedimentasi adalah rata - rata nilai dari setiap titik lokasi selama 15 hari dari stasiun 1 (muara Socah) dan stasiun 2 (muara Porong). Adapun peta laju sedimentasi disetiap titik lokasi disajikan pada Gambar 3 dan Gambar 4

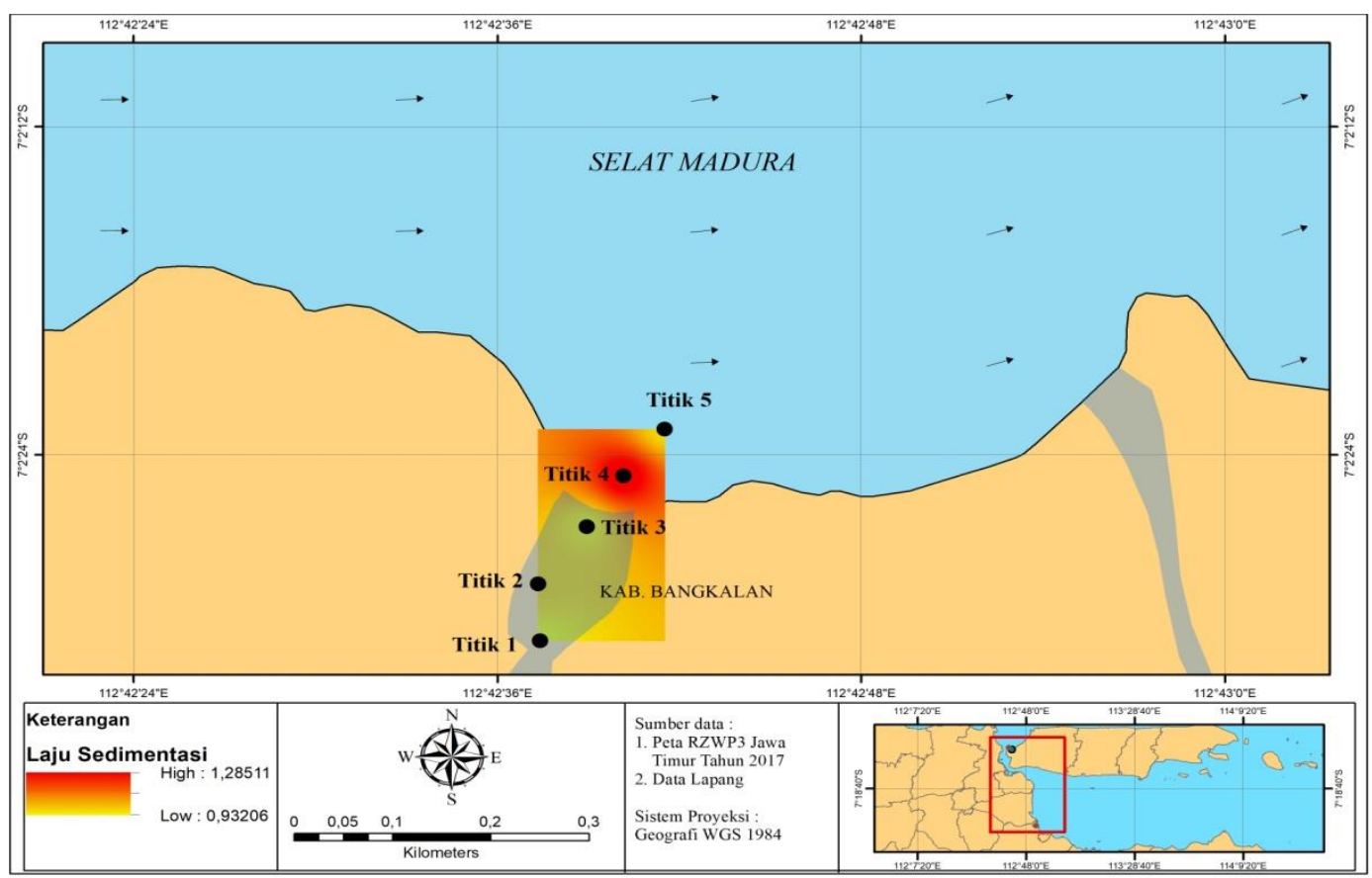

Gambar 3. Peta Laju Sedimentasi Muara Socah dengan Arus Pasang 


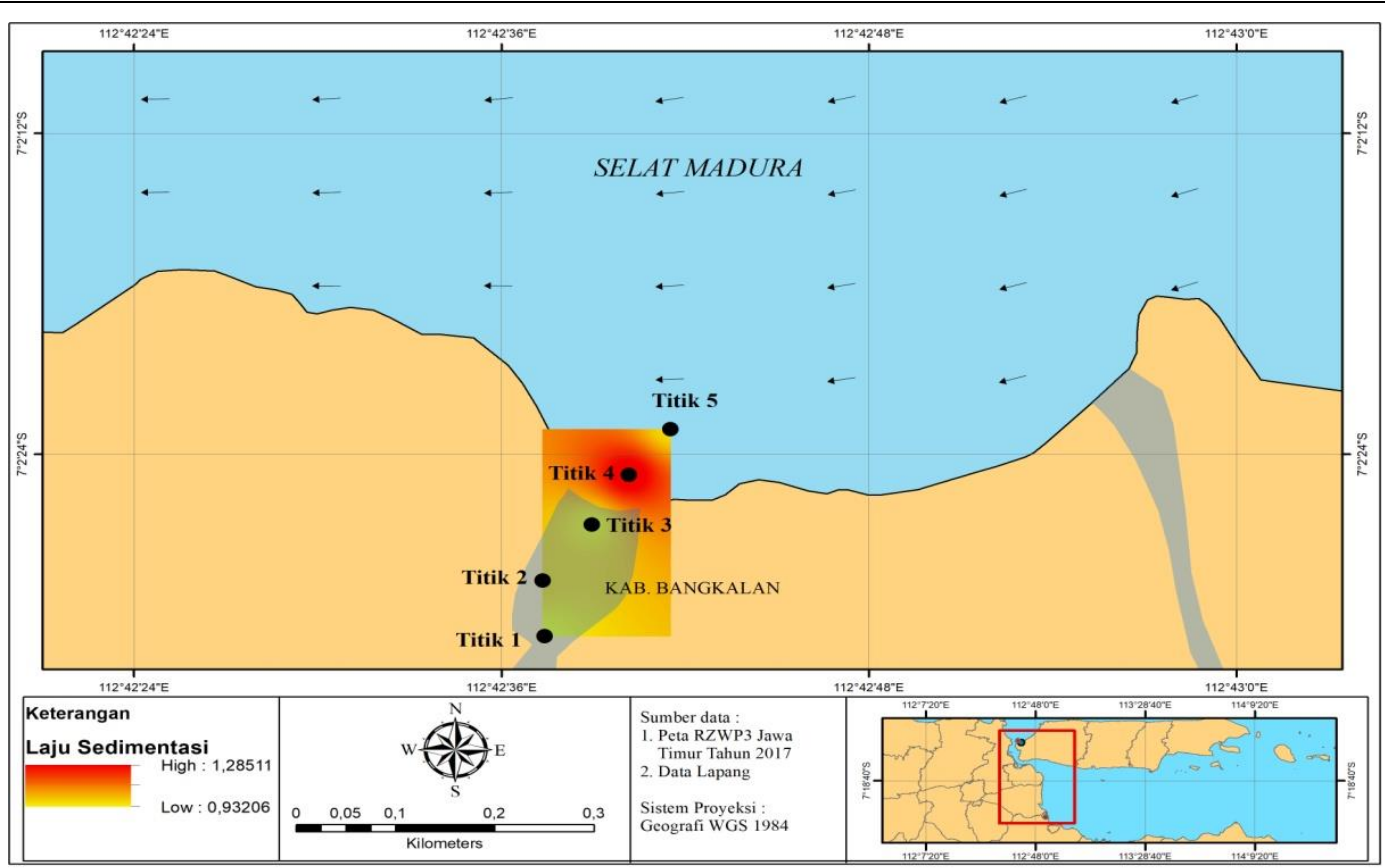

Gambar 4. Peta Laju Sedimentasi Muara Socah dengan Arus Surut

Gambar peta di bawah telah diklasifikasikan dengan warna, yang menunjukkan bahwa warna merah adalah titik lokasi dengan nilai laju sedimentasi terbesar dan warna kuning dengan nilai terendah. Berdasarkan gambar di bawah, titik 3 memiliki warna merah dengan nilai laju sedimentasi terbesar yaitu $1,28512 \mathrm{~m}^{3} /$ hari .

Titik 1 merupakan daerah yang dipengaruhi oleh aliran sungai yang cukup deras. Daerah ini berada di tengah mulut sungai dan merupakan tempat bertemunya aliran air dari sungai dan air dari laut, sehingga terjadi pergerakan aliran yang cukup kencang pada daerah ini. Sehingga material - material sedimen tersuspensi akan menyebar dan mengendap pada daerah sekitar titik karena terbawa oleh aliran yang cukup kuat.

\section{Muara Porong}

Berdasarkan hasil laju sedimentasi yang didapat akan dilakukan pengklasifikasian tingkat nilai laju sedimentasi dalam bentuk peta. Nilai yang diplotkan pada peta laju sedimentasi adalah rata - rata nilai dari setiap titik lokasi selama 15 hari dari stasiun 2 (muara Porong). Peta laju sedimentasi pada stasiun 2 (Porong) disajikan pada Gambar 5. Dan Gambar 6. Pada stasiun 2 (muara Porong) memiliki jenis substrat berlumpur. Lima titik lokasi yang dipilih telah mewakili daerah yang mengalami sedimentasi yang cukup tinggi. Gambar peta di bawah telah diklasifikasikan dengan warna yang menunjukkan bahwa warna merah adalah titik lokasi dengan nilai laju sedimentasi terbesar dan warna kuning dengan nilai terendah. Pada kondisi pasang arus berasal dari arah tenggara dan selatan menuju utara. Arus dari selatan masuk ke daerah muara yang menuju titik ke 4 . Sedangkan pada kondisi surut arus berasal dari utara menuju ke selatan pada bagian utara muara. Pada bagian selatan muara, arus berasal dari selatan masuk ke daerah muara ke arah barat muara. Pada titik 1 mendapatkan pengaruh arus dari arah utara menuju ke arah barat daya, dan pada titik ke 5 arah arus tidak beraturan dimana arus menuju timur, selatan, utara dan barat. 


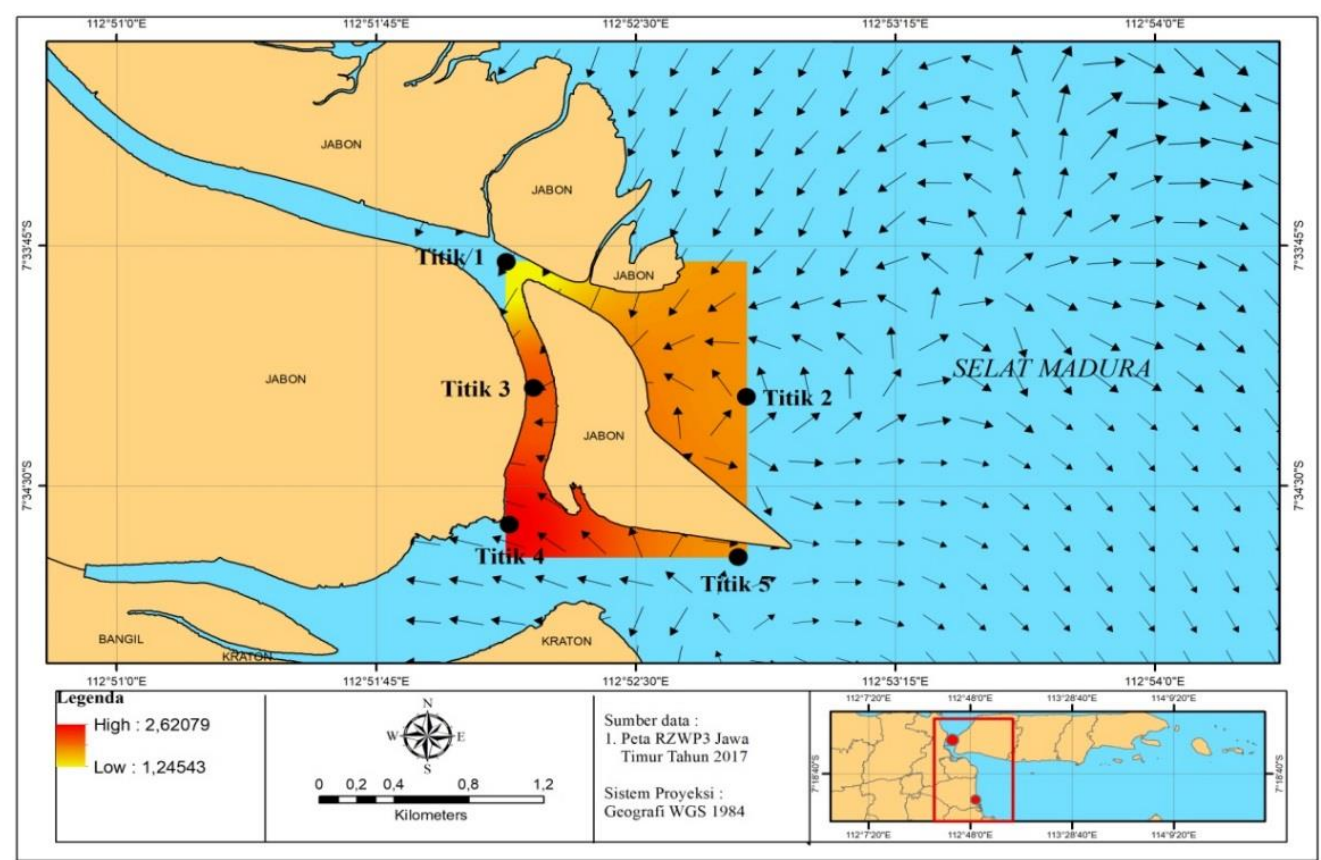

Gambar 5. Peta Laju Sedimentasi Muara Porong dengan Arus Pasang

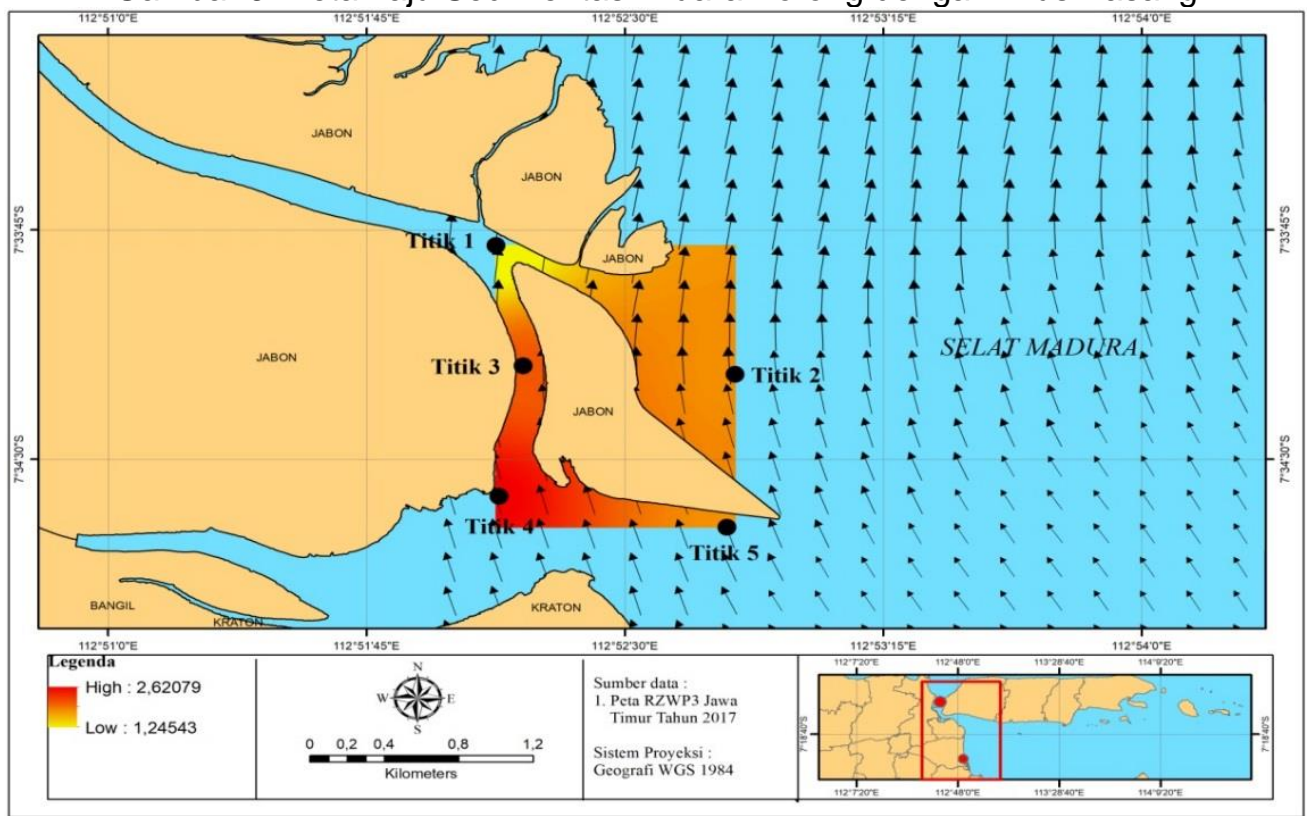

Gambar 6. Peta Laju Sedimentasi Muara Porong dengan Arus surut

Suplai material sedimen yang mengendap pada muara Porong dialirkan oleh Sungai Porong dan beberapa anak sungai yang bermuara di muara Porong dan juga dari laut. Titik 4 terletak dekat dengan ekosistem mangrove dan dipengaruhi oleh muara sungai lain. Sehingga jumlah sedimen yang mengendap pada titik 4 memiliki nilai yang besar. Tingkat laju sedimentasi yang tinggi pada titik ini juga dipengaruhi oleh arus pasang surut. Pada titik 1 pengendapan yang terjadi relatif lebih kecil dibandingkan dengan titik titik yang lain. Lokasi titik 1 terletak di perpecahan muara karena adanya pulau Lusi yang berada di tengah muara. Aliran sungai Porong memiliki kecepatan yang sangat tinggi, sehingga pada titik 1 arus akan menghantam pada depan pulau yang mengakibatkan arus berbelok ke arah aliran sisi kanan dan kiri pulau.

\section{Uji Statistik (Independent T-Test) Hasil Laju Sedimentasi}

Uji indepent sampel T test menunjukkan bahwa nilai laju sedimentasi muara Socah dan Porong berbeda secara nyata berdasarkan nilai sig 2 tailed 0,000<0,05. Dibuktikan bahwa laju Porong lebih tinggi dibandingkan Socah kaerana mendapatkan suplai sedimen dari pembuangan lumpur lapindo (Pahlevi dan Wiweka, 2010). 


\section{Jenis Sedimen}

Hasil analisa laboratorium digunakan untuk mengetahui pengelompokan dari jenis sedimen. Hasil analisa diplotkan pada segitiga sedimen untuk mengetahui jenis sedimen pada setiap titik lokasi. Berdasarkan hasil perhitungan nilai \% Kumulatif, \% Lolos dan \% Tertahan diperoleh kesimpulan berupa nilai \% Silt, \% Sand dan \% Clay. Jenis sedimen pada kedua lokasi tersebut di semua titiknya termasuk dalam jenis Silt. Rata-rata jenis sedimen pada kedua stasiun memiliki nilai silt diatas 93,83\% - 99,84\%.Jenis sedimen ini banyak ditemukan di daerah muara karena dipengaruhi oleh arus yang tenang (Kusnida et al., 2014).

\section{Parameter Hidrooseanografi Pasang Surut}

Parameter hidrooseanografi memiliki peranan penting dalam suatu perairan salah satunya dalam terjadinya proses sedimentasi atau laju sedimentasi. Salah satu faktor hidrooseanografi yang mempengaruhi terjadinya sedimentasi adalah pasang surut, debit sungai dan arus. Parameter tersebut mempengaruhi sebaran sedimen serta mempengaruhi kecepatan dari sedimen untuk mengendap dan jenis dari sedimen pada suatu daerah. Pasang surut merupakan gerakan naik turunnya permukaan air laut yang dipengaruhi oleh gaya tarik - menarik antar benda angkasa terhadap massa air di bumi (Firdaus dan Tridoyo, 2014).

Menurut Srijati et al. (2017), pasang surut merupakan salah satu faktor yang sangat berperan pada terjadinya sedimentasi pada suatu daerah muara selain debit sungai. Pada saat kondisi pasang, angkutan sedimen laut akan terbawa menuju daerah muara, sebaliknya saat kondisi surut angkutan sedimen sungai akan terangkut menuju daerah muara. Pertemuan angkutan sedimen dari laut dan sungai di daerah muara megalami pengendapan dan mengakibatkan pendangkalan pada daerah tersebut. Grafik pasang surut dapat dilihat pada Gambar 7. dan 8.

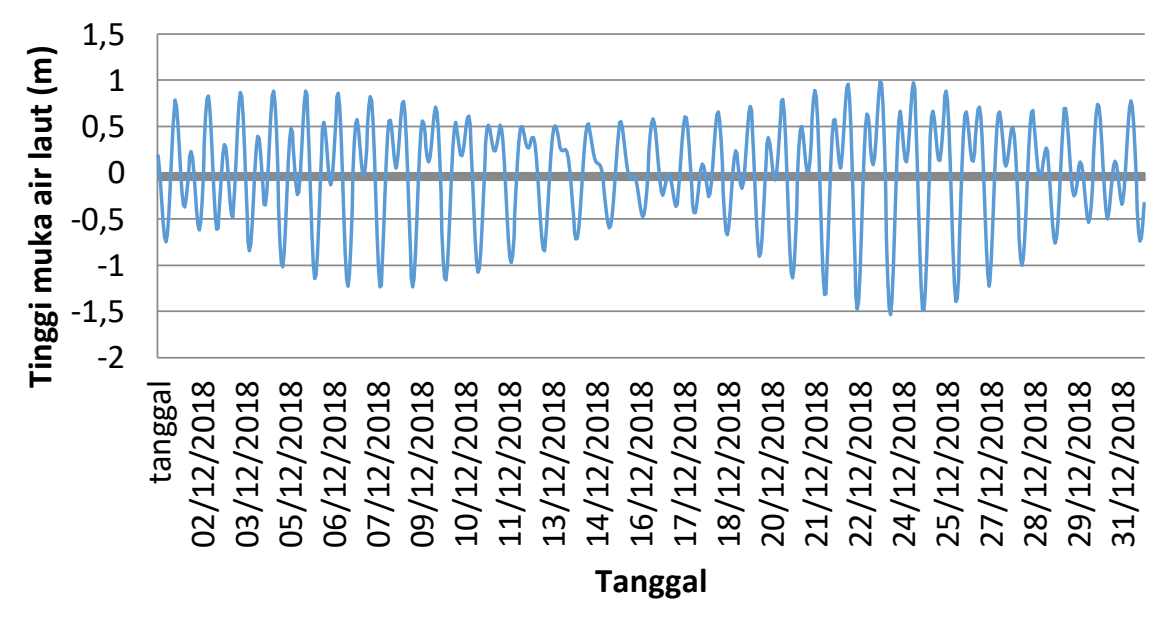

Gambar 7. Grafik Pasang Surut Perairan Porong

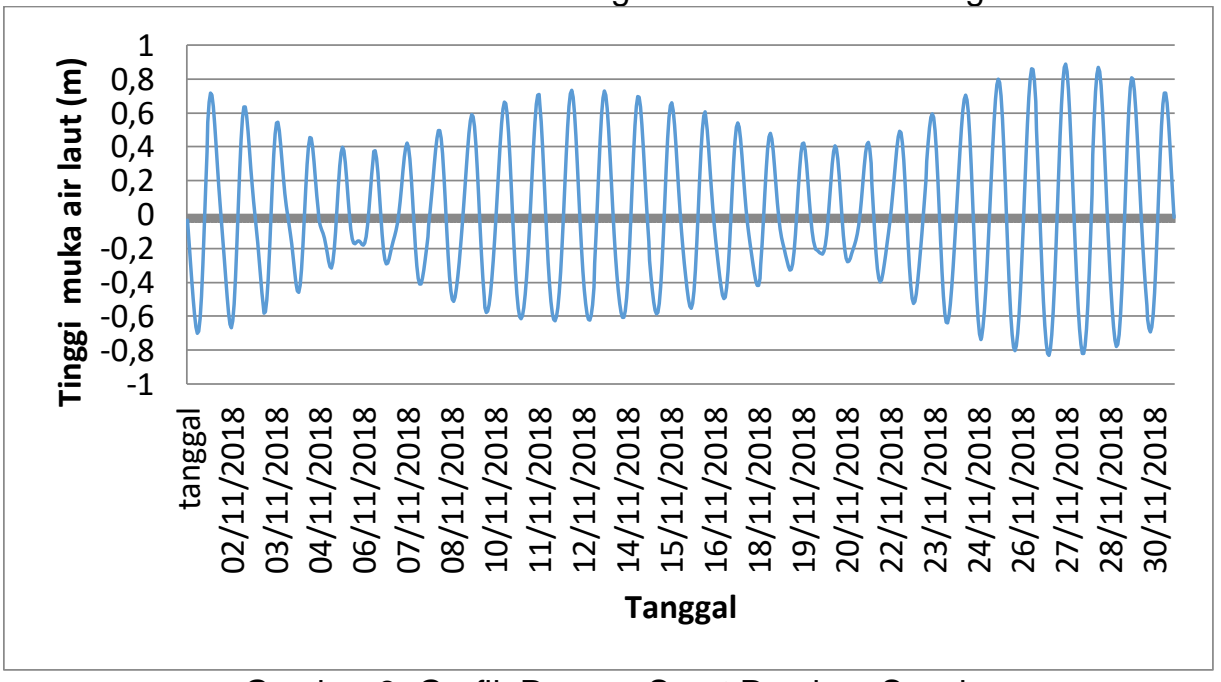

Gambar 8. Grafik Pasang Surut Perairan Socah 
Berdasarkan persamaan Fromzahl, tipe pasang Surut di perairan Selat Madura sekitar kawasan muara sungai Socah dan perairan Porong Sidoarjo adalah pasang surut campuran condong harian ganda yang menunjukkan terjadi 2 kali pasang dan 2 kali surut dalam satu hari dengan waktu dan ketinggian yang berbeda.

\section{Arus Laut}

Arus laut adalah salah satu parameter hidrooseanografi yang mempunyai peran penting dalam mengontrol terjadinya transpor sedimen di suatu perairan. Arus menghasilkan energi yang mampu membawa dan memindahkan sedimen dari suatu tempat ke tempat yang lain. Peta sebaran arus muara Porong dapat dilihat pada Gambar 9 dan Gambar 10. Berdasarkan Gambar 9. diketahui saat kondisi pasang, kecepatan arus laut di Perairan Muara Porong berkisar antara 0,063 $\mathrm{m} / \mathrm{s}-0,127 \mathrm{~m} / \mathrm{s}$ dengan arah arus dominan bergerak dari arah selatan menuju ke utara. Kecepatan arus rata - rata saat kondisi pasang yaitu $0,084 \mathrm{~m} / \mathrm{s}$.

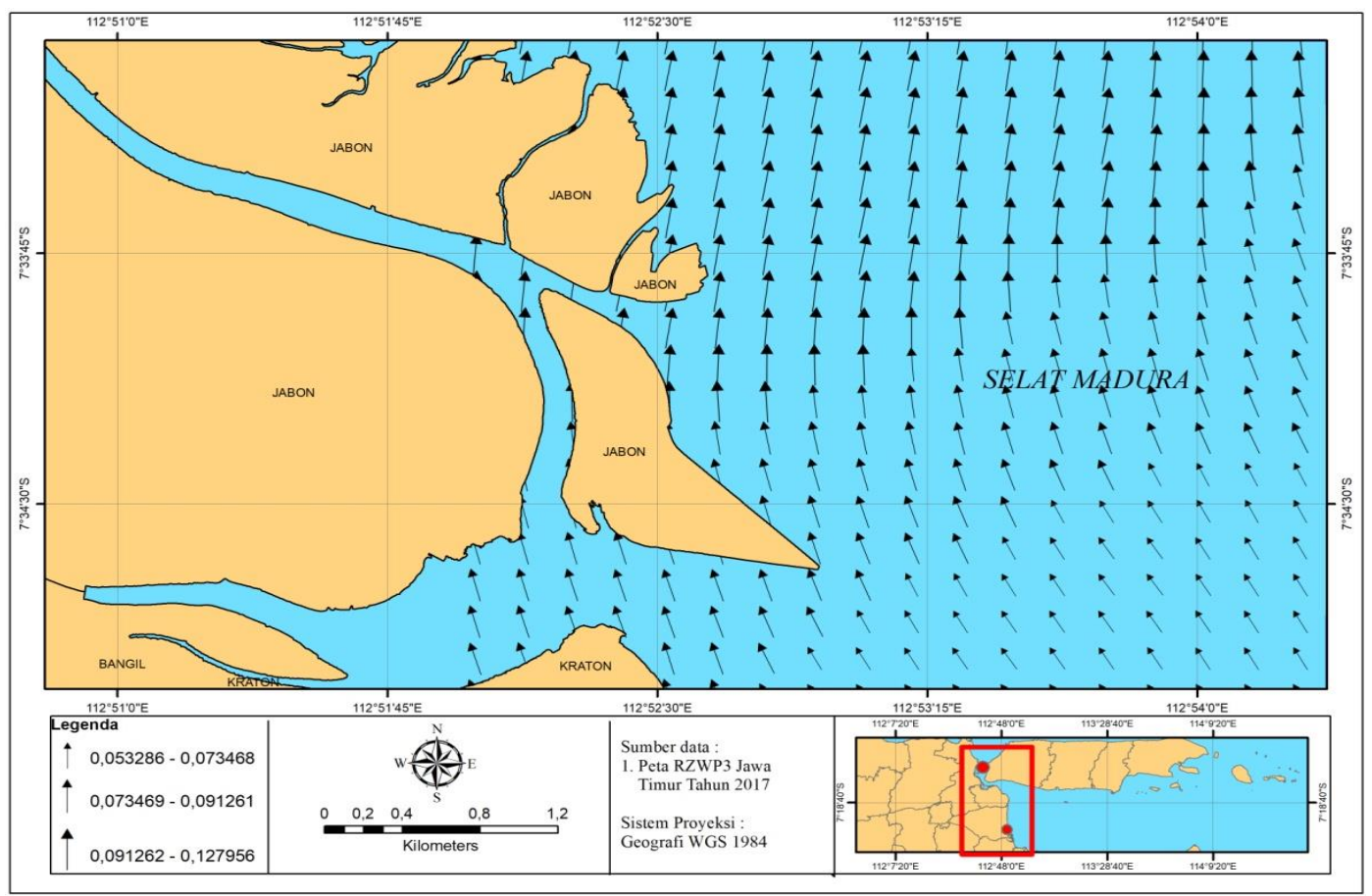

Gambar 9. Peta Sebaran Arus Kondisi Pasang di Perairan Porong 


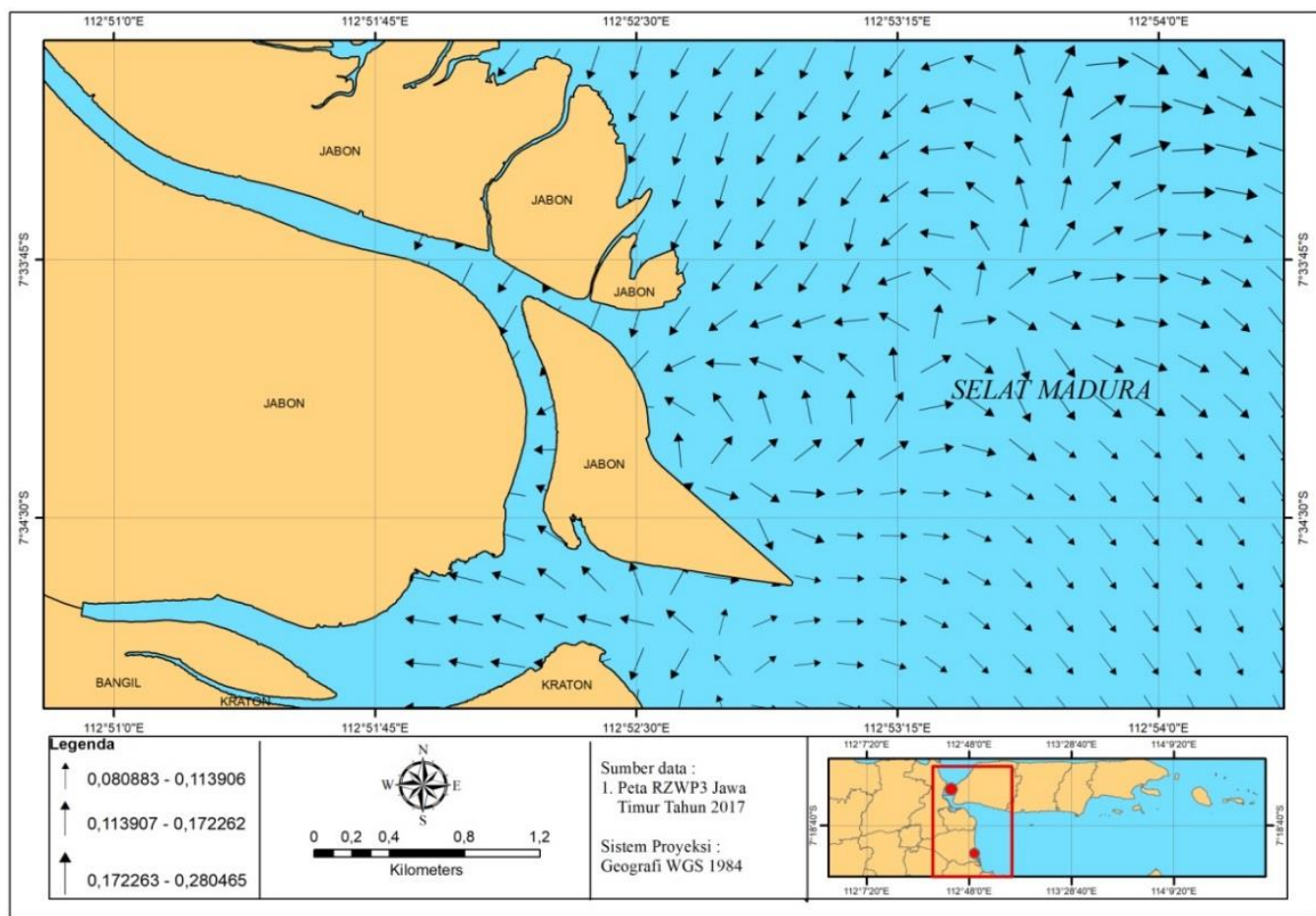

Gambar 10. Peta Sebaran Arus Kondisi Surut di Perairan Porong

Berdasarkan Gambar 10. diketahui bahwa kecepatan arus saat kondisi surut berkisar antara $0,060 \mathrm{~m} / \mathrm{s}-0,280 \mathrm{~m} / \mathrm{s}$ dengan arus yang tidak beraturan. Arus laut saat kondisi surut mempunyai kecepatan rata - rata yaitu 0,134 $\mathrm{m} / \mathrm{s}$. Saat kondisi surut kecepatan arus tertinggi berada di laut daerah laut lepas dan tidak terhalang oleh ekosistem apapun, sehingga arus laut yang sampai di daerah tersebut tinggi karena tidak ada hambatan.

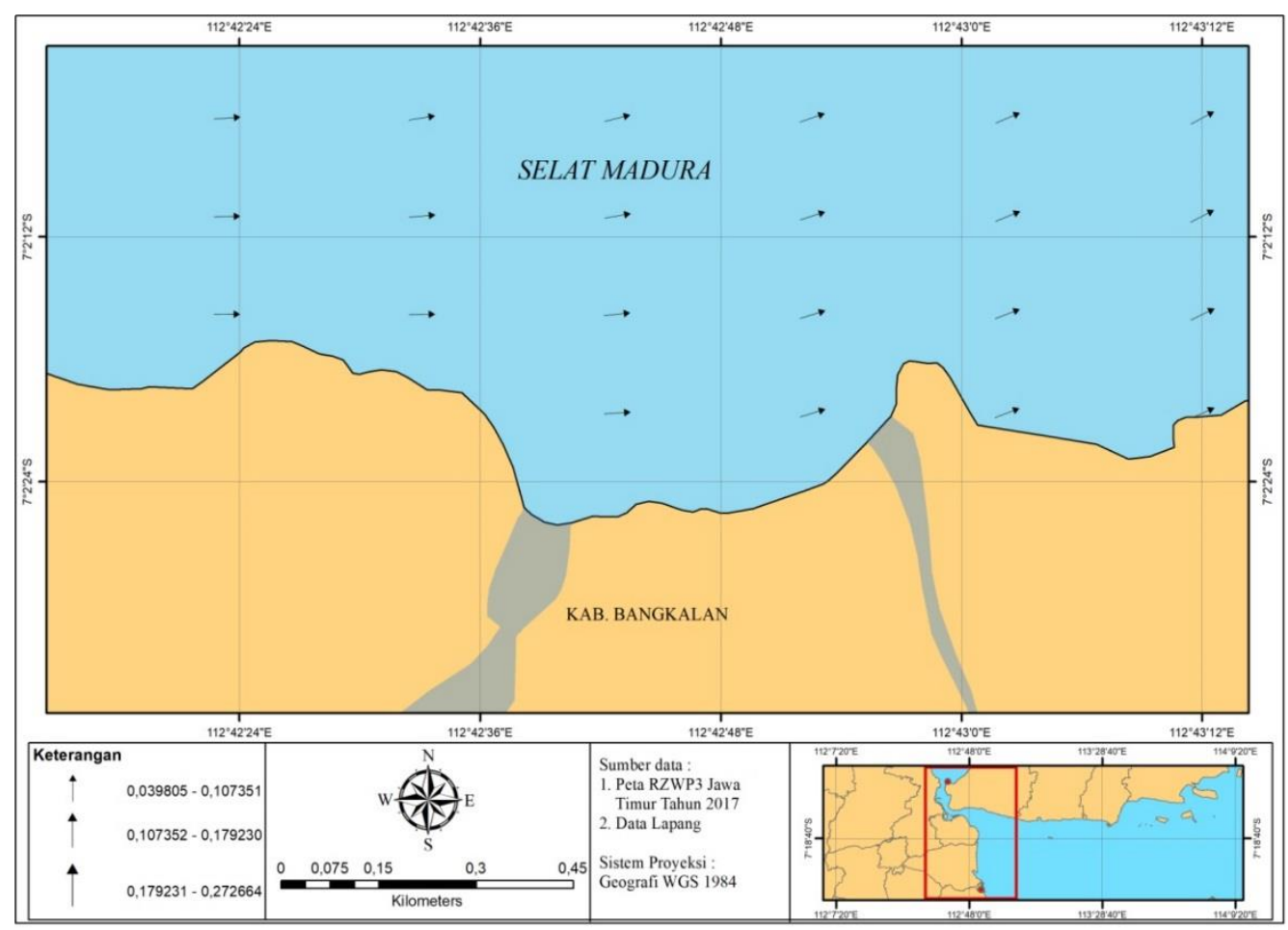

Gambar 11. Peta Sebaran Arus Kondisi Pasang di Perairan Socah 


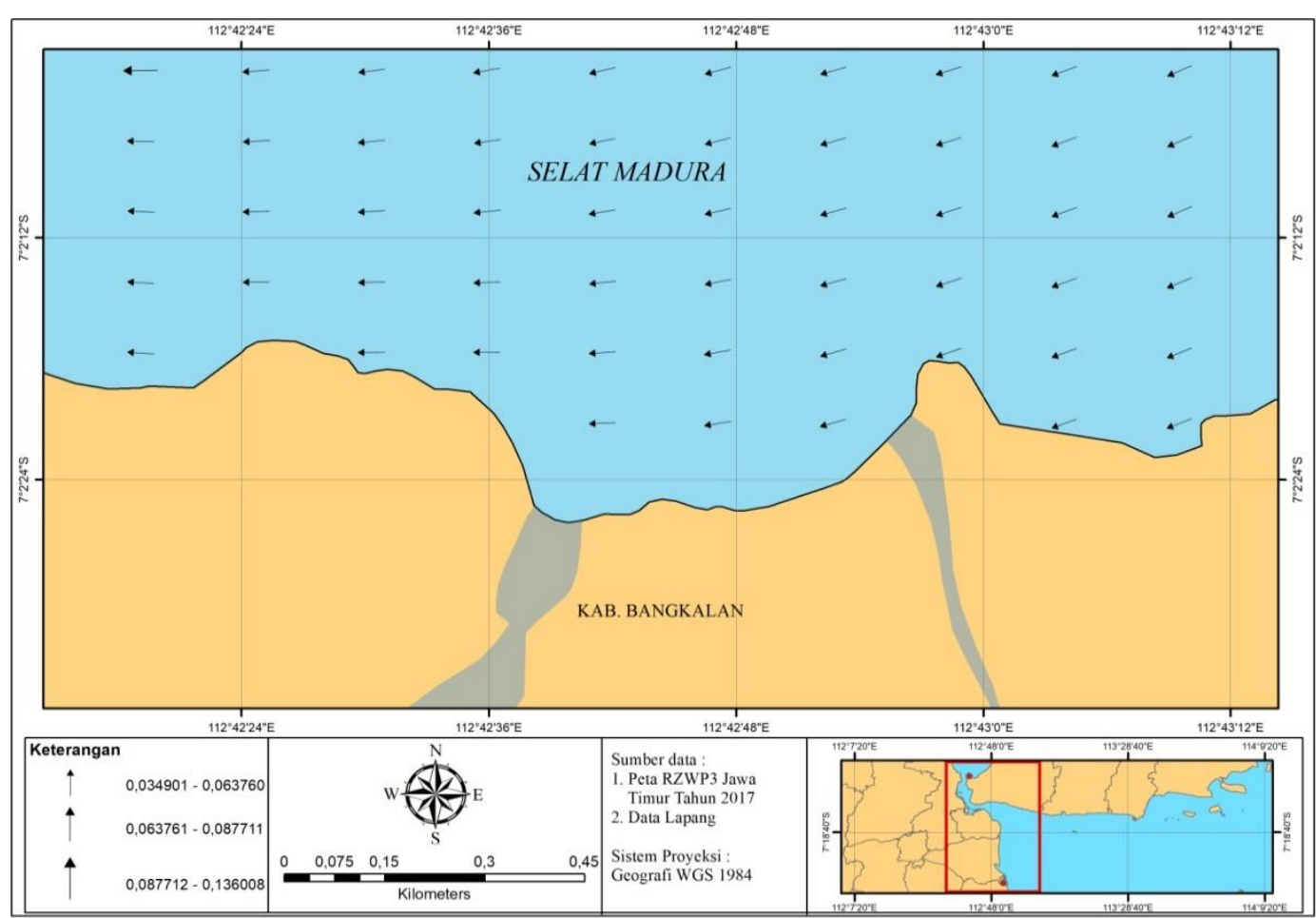

Gambar 12. Peta Sebaran Arus Kondisi Surut di Perairan Socah

Berdasarkan Gambar 11. diketahui pada saat kondisi pasang, kecepatan arus laut di perairan muara socah berkisar antara $0,039 \mathrm{~m} / \mathrm{s}-0,272$ $\mathrm{m} / \mathrm{s}$ dengan arah arus dominan bergerak dari arah barat menuju timur. Kecepatan rata - rata saat kondisi pasang yaitu $0,078 \mathrm{~m} / \mathrm{s}$. Arus yang melewati daerah muara Socah kecepatan yang relatif sama dan bernilai kecil. Pola arus saat kondisi surut dapat dilihat pada Gambar 12. dengan kecepatan yang berbeda - beda. Berdasarkan hasil tersebut diketahui bahwa kecepatan arus saat kondisi surut berkisar antara $0,034 \mathrm{~m} / \mathrm{s}-0,136 \mathrm{~m} / \mathrm{s}$ dengan arah arus yang bersal dari timur ke barat. Arus laut saat kondisi surut mempunyai kecepatan rata - rata yaitu $0,067 \mathrm{~m} / \mathrm{s}$. Kecepatan arus arus pada daerah muara mempunyai nilai yang rendah dikarenakan di sekitar muara terdapat mangrove sehingga arus yang masuk akan menjadi lambat.

\section{Kesimpulan}

\section{KESIMPULAN DAN SARAN}

Hasil pengolahan data laju sedimentasi dan analisa sampel sedimen di muara Sungai Socah dan Porong dapat disimpulkan bahwa Nilai laju sedimentasi di Porong memiliki nilai lebih besar yaitu $1,98 \mathrm{~m}^{3} /$ hari jika dibandingkan dengan muara Socah sebesar $1,02 \mathrm{~m}^{3} /$ hari. Laju sedimentasi terbesar di muara Socah di titik ke 3 sebesar $1,28512 \mathrm{~m}^{3} /$ hari dan nilai terendah di titik ke 1 sebesar 0,93206 $\mathrm{m}^{3} /$ hari. Laju sedimentasi terbesar di muara Porong di titik ke 4 dengan nilai 2,62080 $\mathrm{m}^{3} / \mathrm{hari}$ dan nilai terendah pada titik ke 1 sebesar 1,24543 $\mathrm{m}^{3} /$ hari.

\section{Saran}

Perlu adanya pembaruan terhadap alat pengambilan sampel sedimen agar lebih praktis dan efektif serta adanya penelitian lebih lanjut mengenai laju sedimentasi pada musim kemarau dan musim penghujan untuk mengetahui pengaruh musim terhadap besar kecilnya nilai laju sedimentasi.

\section{DAFTAR PUSTAKA}

Putra, J. R., Rifardi, R., \& Mubarak, M. ANALISIS SEDIMENTASI DI MUARA SUNGAI ROKAN PROVINSI RIAU. Berkala Perikanan Terubuk, 44(1), 90-103.

Triatmodjo, B. (1999). Teknik Pantai. Swadaya: Jakarta.

Hambali, R., \& Apriyanti, Y. (2016, December). Studi Karakteristik Sedimen Dan Laju Sedimentasi Sungai Daeng-Kabupaten Bangka Barat. In FROPIL (Forum Profesional Teknik Sipil) (Vol. 4, No. 2, pp. 165-174).

Rifardi. 2008. Tekstur Sedimen:Sampling dan Analisis. Pekanbaru: UNRI Press.

Rifardi. (2012). Ekologi Sedimen Laut Modern (Edisi Revisi). Riau: UR Press.

Pradipta, Y., Saputro, S., \& Satriadi, A. (2013). Laju Sedimentasi Di Muara Sungai Slamaran Pekalongan. Journal of Oceanography, 2(4), 378-386.

Srijati, S., Rochaddi, B., \& Widada, S. (2017). Analisis Laju Sedimentasi Di Perairan Muara 
Sungai Waridin Kabupaten Kendal. Journal of Oceanography, 6(1), 246-253.

Fajarin, S. N., Saputro, S., \& Hariadi, H. (2014). Laju Sedimentasi Di Muara Sungai Semat Jepara. Journal of Oceanography, 3(4), 560565.

Pahlevi, A. M., \& Wiweka, W. (2010). Analisa Sedimentasi di Muara kali Porong Akibat Pembuangan Lumpur Lapindo Menggunakan Data Citra Satelit ASTER. GEOMATIKA, 16(2), 23-42.

Kusnida, D., Reza, R dan Lukman, A. (2014). Distribusi Sedimen Permukaan Dasar Laut dan Jenis Mineral Lempung di Cekungan Spermonde, Sulawesi Selatan. Majalah Geologi Indonesia, 29(1), 49-61.

Firdaus, A. M., Kusumastanto, T., \& Nurjaya, I. W. (2014). Analisis Kelayakan Teknis dan Finansial Pengembangan Energi Arus Laut di Selat Madura. Jurnal Aplikasi Manajemen, 12(3), 512-520. 